\title{
The Influence of Emotional Intelligence and Organizational Commitment on Employee Performance at the Department of Labor and Transmigration of Seluma Regency
}

\section{Pengaruh Kecerdasan Emosional dan Komitmen Organisasi terhadap Kinerja Pegawai pada Dinas Ketenagakerjaan dan Transmigrasi Kabupaten Seluma}

\author{
Lina Yuniarti1); Ermy Wijaya2); Yesi Indian Ariska2) \\ 1)Study Program of Management, Faculty of Economic, Universitas Dehasen Bengkulu \\ ${ }^{2)}$ Department of Management, Faculty of Economic, Universitas Dehasen Bengkulu \\ Email: ${ }^{1)}$ linayuniarti727@gmail.com; ${ }^{2)}$ ermy.wijaya04@gmail.com; ${ }^{2)}$ yesiindian@yahoo.com
}

How to Cite:

Yuniarti, L., Wijaya, E., Ariska, Y. I. (2021). The Influence of Emotional Intelligence and Organizational Commitment on Employee Performance at the Department of Labor and Transmigration of Seluma Regency. EMAK: Jurnal Ekonomi Manajemen Akuntansi Dan Keuangan, 2(4). DOI: https://doi.org/10.53697/emak.v2i4

ARTICLE HISTORY

Received [20 Agust 2021]

Revised [25 Agust 2021]

Accepted [05 October 2021]

KEYWORDS

Emotional Intelligence,

Organizational Commitment,

Performance

This is an open access article under the $C C-B Y$-SA license

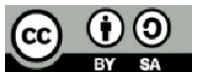

\section{ABSTRAK}

Tujuan penelitian ini adalah mengetahui pengaruh kecerdasan emosional dan komitmen organisasi secara bersama-sama terhadap kinerja Pegawai pada Dinas Ketenagakerjaan dan Transmigrasi Kabupaten Seluma.Sampel dalam penelitian ini 52 orang Pegawai pada Dinas Ketenagakerjaan dan Transmigrasi Kabupaten Seluma Pengumpulan data menggunakan kuesioner dan metode analisis yang digunakan adalah regresi linier berganda, uji determinasi dan uji hipotesis. Hasil regresi berganda menunjukan persamaan $Y=6,045+$ $0,419 \times 1+0,458 \times 2$, arah regresi yang dihasilkan adalah positif sehingga mengandung arti bahwa semakin meningkat variabel kecerdasan emosional dan komitmen organisasi maka kinerja pegawai juga akan meningkat. Nilai koefesien determinasi sebesar 0,595. Hal ini berarti bahwa X1 (kecerdasan emosional) dan X2 (komitmen organisasi) memiliki kontribusi terhadap kinerja $(Y)$ sebesar 59,5\% sedangkan sisanya 40,5\% dipengaruhi oleh variabel-variabel lainnya yang tidak diteliti dalam penelitian ini. Secara keseluruhan, hasil uji t memiliki nilai signfikan lebih kecil dari 0,05, sehingga dapat diartikan bahwa X1 (kecerdasan emosional) dan X2 (komitmen organisasi) memiliki pengaruh yang signfikan terhadap kinerja $(Y)$ secara parsial atau sendiri-sendiri. Hasil uji F memiliki nilai signifikansi sebesar 0,000 $<0,05$. Karena tingkat signifikansi di bawah 0,05 menunjukkan bahwa secara bersama-sama X1 (kecerdasan emosional) dan X2 (komitmen organisasi) mempunyai pengaruh yang signifikan terhadap kinerja $(Y)$.

\section{ABSTRACT}

The purpose of this study is to determine the influence of emotional intelligence and organizational commitment on employees' performance at the Department of Labor and Transmigration of Seluma Regency. The sample in this study was 52 employees at the Department of Labor and Transmigration of Seluma Regency. The data was collected using a questionnaire and the analytical methods used were multiple linear regression, determination test and hypothesis testing. The results of 
multiple regressions show that the equation $Y=6.045+0.419 X 1+0.458$ $X 2$. The result of regression direction is positive, meaning that the higher emotional intelligence and organizational commitment variables, the higher the employees' performance will also be. The value of the coefficient of determination is 0.595 . This means that $X 1$ (emotional intelligence) and $X 2$ (organizational commitment) have a contribution to performance $(Y)$ of $59.5 \%$ while the remaining $40.5 \%$ is influenced by other variables not examined in this study. Overall, the results $t$ test has a significant value is less than 0.05 , so it can be interpreted that X1 (emotional intelligence) and $X 2$ (organizational commitment) have a significant influence on performance $(Y)$ partially or individually. The results of the $F$ test have a significant value of $0.000<0,05$. Because the level of significance below 0.05 indicates that X1 (emotional intelligence) and X2 (organizational commitment) have a significant influence on performance $(Y)$..

\section{PENDAHULUAN}

Sejalan dengan semakin tingginya tingkat perkembangan dari berbagai sektor, banyak organisasi berupaya untuk menata ulang serta mengelola sumber daya manusianya sebaik mungkin sesuai dinamika perkembangan yang terjadi saat ini. Salah satu diantaranya ialah sektor pemerintahan, yang kerap kali dihadapkan pada suatu kondisi dimana keberadaannya sebagai pelayan publik dituntut untuk mengoptimalkan pelayanannya kepada masyarakat secara efektif dan efisien, serta dalam upaya menyiasati perubahan baik dari segi struktur maupun kultur. Melalui fungsinya tersebut, Sumber Daya Manusia diharapkan dapat mensinergikan peranannya dalam usaha meningkatkan kinerja yang baik. Hal tersebut tentunya menjadi perhatian bagi instansi pemerintahan untuk menunjang potensi yang dimiliki oleh masing - masing individu melalui manajemen Sumber Daya Manusia.

Manajemen Sumber Daya Manusia memungkinan suatu organisasi untuk memperoleh serta mempertahankan pegawai yang memiliki kapasitas dalam berkontribusi, cakap dan terampil dalam menyelesaikan tugas, serta membantu menciptakan lingkungan kerja yang kondusif bagi kemajuan Sumber Daya Manusia itu sendiri. Dalam konteks manajemen, pencapaian tujuan organisasi secara manajerial diawali dengan fungsi perencanaan. Keterlibatan komponen Sumber Daya Manusia dalam perencanaan memiliki peran yang tidak hanya terbatas dalam hal fungsional semata, namun lebih dari itu mencakup peran substansial sebagai pendukung transformasi dari input menjadi output. Lebih lanjut, keberhasilan seorang pegawai pada akhirnya dapat dilihat pada kinerja yang dicapainya dalam kurun waktu tertentu. Sehingga kinerja pegawai diasumsikan sebagai bagian dari hasil, dan untuk memperoleh hasil kerja yang baik maka seorang pegawai membutuhkan dukungan dan lingkungan yang baik pula guna menunjang potensinya.

Tujuan organisasi akan tercapai jika terdapat semangat kerja yang tinggi dari para pegawainya. Dalam konteks hasil, kinerja merupakan catatan hasil yang diproduksi (dihasilkan) atas fungsi pekerjaan tertentu atau aktivitas - aktivitas selama periode waktu tertentu. Kinerja ini kemudian menjadi sorotan bagi organisasi pemerintahan dalam mengartikulasikan hal - hal apa saja yang dapat menunjang bagi peningkatan kinerja sehingga terciptanya keunggulan bersaing yang berkelanjutan atau dikenal dengan istilah sustainable competitive advantage (Martin, 2015:55).

Dinas Ketenagakerjaan dan Transmigrasi Kabupaten Seluma mempuyai tugas melaksanakan sebagian urusan pemerintahan daerah berdasarkan asas otonomi dan tugas pembantuan di bidang Tenaga Kerja, Pemberdayaan Masyarakat dan Transmigrasi. Pegawai merupakan salah satu unsur penting dalam instansi, tanpa pegawai maka suatu instansi tidak akan berjalan dengan baik. Pegawai memiliki beban kerja yang berat, bukan saja dari segi privasi yang terbatas, dan jam kerja yang padat, namun juga dari desakan dari pimpinan yang menginginkan pekerjaan cepat diselesaikan dan pimpinan tidak mau tau dengan kesulitan yang dihadapi pegawai. 
Selama ini terlihat bahwa tingginya tanggung jawab seorang Pegawai karena banyaknya tugas dan tanggungjawab yang harus diselesaikan tepat waktu. Pada kenyataannya dapat dilihat masih kurangnya kecerdasan emosional yang dimiliki oleh pegawai Dinas Ketenagakerjaan dan Transmigrasi Kabupaten Seluma. Hal ini terlihat pada pegawai yang masih merasa kepanikan pada saat adanya tekanan kerja yang tinggi. Tekanan kerja dan rutinitas kerja memerlukan dukungan mental yang mampu mengendalikan dan mengelola emosi secara positif, serta mampu memotivasi diri sendiri, mampu mengenali emosi orang lain, dan mampu membina hubungan dengan orang lain, sehingga akan terjalin hubungan saling percaya dan saling membantu antara pegawai dengan sesama pegawai dan antara pegawai dengan pimpinan.

\section{LANDASAN TEORI}

\section{Manajemen Sumber Daya Manusia}

Menurut Sutrisno (2014:4), manajemen sumber daya manusia merupakan pengakuan tentang pentingnya tenaga kerja organisasi sebagai sumber daya manusia yang sangat penting dalam memberi kontribusi bagi tujuan-tujuan organisasi, dan menggunakan beberapa fungsi dan kegiatan untuk memastikan bahwa sumber daya manusia tersebut digunakan secara efektif dan adil bagi kepentingan individu, organisasi dan masyarakat.

\section{Kecerdasan Emosional}

Menurut Shapiro (2016:34), menyatakan bahwa kecerdasan emosional ialah himpunan bagian dari kecerdasan sosial yang melibatkan kemampuan memantau perasaan sosial yang melibatkan kemampuan pada orang lain, memilah-milah semuanya dan menggunakan informasi ini untuk membimbing pikiran dan tindakan. Sedangkan Goleman, (2015:34) mendefinisikan kecerdasan emosional sebagai serangkaian kemampuan pribadi, emosi dan sosial yang mempengaruhi kemampuan seseorang untuk berhasil dalam mengatasi tuntutan dan tekanan lingkungan.

\section{Kualitas Pelayanan}

Menurut Soegito (2017:152) mengemukakan bahwa: "Pelayanan (service) adalah setiap kegiatan atau manfaat yang dapat diberikan suatu pihak kepada pihak lainnya yang pada dasarnya tidak berwujud dan tidak pula berakibat pemilikan sesuatu dan produksinya dapat atau tidak dapat dikaitkan dengan suatu produk fisik. Menurut Sunarto (2013:23) mengemukakan bahwa Pelayanan adalah daya tarik yang besar bagi para pelanggan, sehingga korporat bisnis seringkali menggunakannya sebagai alat promosi untuk menarik minat pelanggan.

Dari definisi diatas bahwa mutu pelayanan berpusat pada upaya pemenuhan kebutuhan dan keinginan konsumen serta ketepatan penyampaiannya untuk mengimbangi harapan konsumen, yaitu adanya kesesuaian antara harapan dengan persepsi manajemen, adanya kesesuaian antara persepsi atas harapan konsumen dengan standar kerja karyawan, adanya kesesuaian antara standar kerja karyawan dengan pelayanan yang diberikan, adanya kesesuaian antara pelayanan yang diberikan dengan pelayanan yang dijanjikan dan adanya kesesuaian antara pelayanan yang diterima dengan yang diharapkan dengan konsumen

\section{Harga}

Zainuddin (2014:25) mendefinisikan "komitmen organisasi sebagai kekuatan yang bersifat relatif dari individu dalam mengidentifikasikan keterlibatan dirinya kedalam bagian organisasi", hal ini dapat ditandai dengan tiga hal, yaitu :

a. Penerimaan terhadap nilai-nilai dan tujuan organisasi.

b. Kesiapan dan kesediaan untuk berusaha dengan sungguh-sungguh atas nama organisasi. 
c. Keinginan untuk mempertahankan keanggotaan di dalam organisasi (menjadi bagian dari organisasi.

Metode Analisis

\section{METODE PENELITIAN}

Regresi Linier Berganda

Menurut Sugiyono (2016:275) regresi berganda digunakan untuk meramalkan bagaimana keadaan (naik turunnya) variabel dependen (kriterium), bila dua atau lebih variabel indenpenden sebagai faktor perdiktor dimanipulasi (dinaik turunkan nilainya). Adapun bentuk persamaan regresi linier berganda menurut Sugiyono (2016:151) adalah sebagai berikut :

$$
\mathrm{Y}=\mathrm{a}+\mathrm{b} 1 \mathrm{X} 1+\mathrm{b} 2 \mathrm{X} 2+\mathrm{e}
$$

Keterangan :

$\mathrm{Y} \quad=$ Kinerja

$\mathrm{X}_{1} \quad=$ Kecerdasan Emosional

$X_{2}=$ Komitmen organisasi

$\mathrm{a} \quad=$ Nilai konstanta

e $\quad=$ erorr

Koefisien Determinasi (R2)

Koefisien determinasi digunakan untuk mengukur seberapa jauh kemampuan model dalam menerangkan variabel dependen. Nilai koefesien determinasi adalah antara 0 dan 1. Nilai R2 yang kecil berarti kemampuan variabel - variabel independen dalam menerangkan variabel dependen sangat terbatas. Nilai yang mendekati 1 berarti variabel independen memberikan hampir semua informasi yang dibutuhkan untuk memprediksi variasi variabel dependen.

\section{Pengujian Hipotesis}

Uji t

Uji t pada dasarnya menunjukkan seberapa jauh pengaruh satu variabel bebas secara individual dalam menerangkan variasi variabel terikat.

Uji $F$

Uji F dilakukan untuk mengetahui pengaruh variabel bebas secara bersama-sama terhadap variabel terikat.

\section{HASIL DAN PEMBAHASAN}

\section{Hasil dan Pembahasan}

Analisis Regresi Linier Berganda

Analisis regresi linier berganda digunakan untuk mengetahui besarnya pengaruh kecerdasan emosional dan komitmen organisasi terhadap kinerja pada Dinas Ketenagakerjaan dan Transmigrasi Kabupaten Seluma. Hasil perhitungan regresi berganda dapat dilihat pada Tabel 1 berikut:

Tabel 1. Model Regresi Linier Berganda

\begin{tabular}{|c|c|c|c|c|c|c|}
\hline \multicolumn{7}{|c|}{ Coefficients $^{\mathrm{a}}$} \\
\hline \multirow{2}{*}{\multicolumn{2}{|c|}{ Model }} & \multicolumn{2}{|c|}{ Unstandardized Coefficients } & \multirow{2}{*}{$\begin{array}{c}\text { Standardized } \\
\text { Coefficients } \\
\text { Beta } \\
\end{array}$} & \multirow[b]{2}{*}{$\mathrm{t}$} & \multirow[b]{2}{*}{ Sig. } \\
\hline & & $\mathrm{B}$ & Std. Error & & & \\
\hline \multirow[t]{3}{*}{1} & (Constant) & 6.045 & 4.183 & & 1.445 & 155 \\
\hline & Kecerdasan Emosional & 419 & .111 & .409 & 3.766 & .000 \\
\hline & Komitmen Organisasi & 458 & .106 & .467 & 4.302 & .000 \\
\hline
\end{tabular}

a. Dependent Variable: Kineria

Sumber: Hasil penelitian dan diolah, 2021 
Berdasarkan Tabel 1 dapat dilihat persamaan regresi yang terbentuk adalah : $\mathrm{Y}=6,045+0,419 \mathrm{X}_{1}+$ $0,458 \mathrm{X}_{2}$

Persamaan regresi tersebut dapat dijelaskan sebagai berikut :

1. Nilai konstanta 6,045 mempunyai arti bahwa apabila variabel Kecerdasan emosional $\left(X_{1}\right)$ dan Komitmen organisasi $\left(\mathrm{X}_{2}\right)$ dianggap tetap maka variabel Kinerja $(\mathrm{Y})$ akan tetap sebesar 6,045

2. Pengaruh Kecerdasan emosional $\left(X_{1}\right)$ terhadap Kinerja $(Y)$

Nilai koefesien regresi variabel $X_{1}$ (Kecerdasan emosional) adalah sebesar 0,419 dengan asumsi apabila $X_{1}$ (Kecerdasan emosional) mengalami kenaikan sebesar satu-satuan maka $Y$ (Kinerja) juga akan mengalami kenaikan sebesar 0,419 kali.

3. Pengaruh Komitmen organisasi $\left(\mathrm{X}_{2}\right)$ terhadap Kinerja $(\mathrm{Y})$

Nilai koefesien regresi variabel $X_{2}$ (Komitmen organisasi) adalah sebesar 0,458 dengan asumsi apabila $X_{2}$ (Komitmen organisasi) mengalami kenaikan sebesar satu-satuan maka $Y$ (Kinerja) juga akan mengalami kenaikan sebesar 0,458 kali.

Koefisien Determinasi $\left(R^{2}\right)$

Tabel 2. Koefesien Determinasi

\begin{tabular}{|l|r|r|r|c|}
\hline \multicolumn{7}{|c|}{ Model Summary } \\
\hline Model & $\mathrm{R}$ & R Square & $\begin{array}{c}\text { Adjusted R } \\
\text { Square }\end{array}$ & $\begin{array}{c}\text { Std. Error of the } \\
\text { Estimate }\end{array}$ \\
\hline 1 & $.771^{\mathrm{a}}$ & .595 & .578 & 1.876 \\
\hline
\end{tabular}

a. Predictors: (Constant), Komitmen Organisasi, Kecerdasan

Emosional

Sumber: Penelitian dan diolah, 2021

Untuk nilai koefesien determinasi menggunakan model $R$ square. Dari hasil perhitungan dengan menggunakan SPSS dapat diketahui nilai koefesien determinasi dari $R$ square yaitu sebesar 0,595. Hal ini berarti bahwa $X_{1}$ (kecerdasan emosional) dan $X_{2}$ (komitmen organisasi) memiliki kontribusi terhadap kinerja ( $Y$ ) sebesar $59,5 \%$ sedangkan sisanya $40,5 \%$ dipengaruhi oleh variabelvariabel lainnya yang tidak diteliti dalam penelitian ini.

Pengujian Hipotesis

Pengujian Hipotesis Secara Parsial (Uji t)

Pengujian hipotesis secara parsial atau uji t bertujuan untuk mengetahui tingkat pengaruh variable $X$ terhadap variable $Y$ secara terpisah atau masing-masing variable $X$ :

1. Variabel $X_{1}$ (Kecerdasan emosional)

Hasil pengujian untuk variabel $X_{1}$ (kecerdasan emosional) menunjukkan nilai signifikansi sebesar $0,000<0,05$. Karena nilai signifikansi lebih kecil dari 0,05, maka $\mathrm{H}_{0}$ ditolak dan $\mathrm{Ha}$ diterima. Artinya $X_{1}$ (kecerdasan emosional ) memiliki pengaruh yang positif dan signifikan terhadap Kinerja $(Y)$.

2. Variabel $X_{2}$ (Komitmen organisasi)

Hasil pengujian untuk variabel $\mathrm{X}_{2}$ (Komitmen organisasi) menunjukkan nilai signifikansi sebesar $0,000<0,05$. Karena nilai signifikansi lebih kecil dari 0,05, maka $\mathrm{H}_{0}$ ditolak dan Ha diterima. Artinya $\mathrm{X}_{2}$ (Komitmen organisasi ) memiliki pengaruh yang positif dan signifikan terhadap Kinerja (Y).

Pengujian Hipotesis Secara Simultan (Uji F)

Uji $F$ digunakan untuk melihat pengaruh seluruh variabel yaitu $X_{1}$ (kecerdasan emosional) dan $\mathrm{X}_{2}$ (komitmen organisasi) berpengaruh secara bersama-sama terhadap kinerja $(\mathrm{Y})$. 
Tabel 3. Pengujian Hipotesis Secara Simultan

\begin{tabular}{|c|c|c|c|c|c|c|}
\hline \multicolumn{7}{|c|}{ ANOVA } \\
\hline \multicolumn{2}{|c|}{ Model } & Sum of Squares & df & Mean Square & $\mathrm{F}$ & Sig. \\
\hline \multirow[t]{3}{*}{1} & Regression & 253.321 & 2 & 126.661 & 35.990 & $.000^{\mathrm{b}}$ \\
\hline & Residual & 172.448 & 49 & 3.519 & & \\
\hline & Total & 425.769 & 51 & & & \\
\hline
\end{tabular}

\section{Sumber: Hasil penelitian dan diolah, 2021}

Berdasarkan Tabel di atas diketahui nilai signifikan sebesar $0,000<0,05$. Karena tingkat signifikan lebih kecil dari 0,05 menunjukkan bahwa secara bersama-sama $\mathrm{X}_{1}$ (kecerdasan emosional) dan $\mathrm{X}_{2}$ (komitmen organisasi) mempunyai pengaruh yang positif dan signifikan terhadap kinerja $(\mathrm{Y})$. Berdasarkan hasil uji simultan maka $\mathrm{H}_{0}$ ditolak dan Ha diterima, antara Variabel-variabel bebas yaitu $\mathrm{X}_{1}$ (kecerdasan emosional) dan $\mathrm{X}_{2}$ (komitmen organisasi) mempunyai pengaruh yang signifikan secara bersama-sama terhadap Kinerja $(\mathrm{Y})$.

\section{Pengaruh Kecerdasan emosional Terhadap Kinerja}

Hasil pengujian pada penelitian ini menunjukkan bahwa terdapat pengaruh yang signifikan antara kecerdasan emosional terhadap kinerja Pegawai pada Dinas Ketenagakerjaan dan Transmigrasi Kabupaten Seluma, karena nilai signifikan sebesar 0,000 kecil dari 0,05. Hal ini menggambarkan bahwa semakin baik kecerdasan emosional pada Dinas Ketenagakerjaan dan Transmigrasi Kabupaten Seluma maka kinerja Pegawai juga akan meningkat. Artinya apabila Pegawai memandang pentingnya kecerdasan emosional maka kinerja akan dapat ditingkatkan.

Hasil hipotesis tersebut sesuai dengan pernyataan Goleman (2015:105) yang mengemukakan bahwa kemampuan kecerdasan emosi adalah pendorong kinerja puncak. Kemampuan-kemampuan kognitif seperti big picture thinking dan long vision juga penting. Tetapi ketika diperbandingkan, antara kemampuan teknikal, kecerdasan intelektual atau IQ, dan kecerdasan emosi sebagai penentu kinerja yang cemerlang tersebut, kecerdasan emosi menduduki porsi lebih penting dua kali dibandingkan dengan yang lain pada seluruh level jabatan.

Pegawai menilai kecerdasan emosional mampu meningkatkan kinerja pegawai dalam bekerja. pegawai telah mampu meghadapi kesulitan dalam bekerja sehingga pegawai mampu mengerjakan semua tugas yang diberikan kepadanya, pegawai menyadari kelebihan dan keselumaangan yang ada dalam dirinya sehingga mereka bisa untuk menghadapi masalah yang timbul dalam bekerja, namun terkadang karena banyaknya pekerjaan membuat pegawai selumaang percaya diri pada kemampuan yang mereka miliki. Untuk itu pegawai harus memiliki kepercayaan pada dirinya bahwa dengan keterampilan dan ilmu yang dimiliki serta pengalaman dalam bekerja mereka mampu menyelesaikan semua pekerjaan yang diberikan kepadanya. Untuk peningkatan kepercayaan diri dari pegawai hal yang dapat dilakukan adalah dengan memberikan pengarahan kepada pegawai dan memberikan keyakinan kepada pegawai bahwa dengan kemampuan yang mereka miliki mereka mampu untuk menyelesaikan semua pekerjaannya.

Untuk meningkatkan kinerja dalam bekerja, pegawai telah mampu melakukan pendekatan dengan orang lain baik dengan atasan maupun teman sekerjanya. Kecerdasan emosi merupakan faktor yang sangat penting bagi organisasi yang secara langsung berhubungan dengan pelanggan (customer) untuk meningkatkan kinerja baik kinerja individu dan organisasi. Menurut Goleman (2015:99), pencapaian kinerja ditentukan hanya 20 persen dari kecerdasan intelektual sedangkan 80 persen lagi ditentukan oleh kecerdasan emosi. Berdasarkan analisis Goleman tersebut, kecerdasan intelektual hanya mengantarkan seseorang ke "pintu gerbang suatu perusahaan", tetapi kemampuan emosional membantu seseorang untuk mengembangkan diri setelah diterima bekerja 
dalam sebuah perusahaan. Kecerdasan emosi merupakan faktor penting untuk dipadukan dengan kombinasi kemampuan teknis dan analisis yang dapat menghasilkan kinerja optima.

Pengaruh Komitmen Organisasi Terhadap Kinerja

Hasil pengujian pada penelitian ini menunjukkan bahwa terdapat pengaruh yang signifikan antara komitmen organisasi terhadap kinerja Pegawai pada Dinas Ketenagakerjaan dan Transmigrasi Kabupaten Seluma karena nilai signifikan sebesar 0,000 lebih kecil dari 0,05. Hal ini menggambarkan bahwa semakin meningkat komitmen organisasi maka kinerja Pegawai pada Dinas Ketenagakerjaan dan Transmigrasi Kabupaten Seluma juga akan semakin meningkat. Artinya dengan adanya komitmen yang tinggi terhadap organisasi akan menciptakan kesetian Pegawai terhadap Dinas Ketenagakerjaan dan Transmigrasi Kabupaten Seluma dan tidak berkeinginan untuk pindah kerja sehingga Pegawai dapat bekerja lebih focus dan dapat meningkatkan kinerja Pegawai.

Kinerja Pegawai dapat ditunjukkan dengan hasil pekerjaan Pegawai di perusahaan, dengan adanya komitmen yang diterapkan dalam diri masing-masing Pegawai, mereka jadi semangat untuk bekerja dan dapat menyelesaikan pekerjaan sesuai dengan standar waktu yang telah ditentukan, selain itu Pegawai dapat menyelesaikan pekerjaan sesuai dengan visi dan misi perusahaan. Hal ini berarti bahwa kinerja Pegawai di Dinas Ketenagakerjaan dan Transmigrasi Kabupaten Seluma akan meningkat ketika komitmen organisasi berada dalam posisi yang tinggi dalam suatu perusahaan.

Hasil penelitian ini sesuai dengan pendapat yang disampaikan oleh Danim (2016:53), bahwa komitmen sebagai sebuah sikap, memiliki ruang lingkup yang lebih global daripada kepuasan kerja, karena komitmen organisasi menggambarkan pandangan terhadap organisasi secara keseluruhan, bukan hanya aspek pekerjaan saja. Komitmen organisasi yang ada pada Pegawai Dinas Ketenagakerjaan dan Transmigrasi Kabupaten Seluma dapat dilihat dari melakukan semua kewajiban yang diberikan kepadanya, selalu memegang teguh tugas dan tanggung jawab, selalu memberikan dukungan kepada semua kegiatan yang akan memajukan organisasi, mendukung semua keputusan yang diambil demi kemajuan instansi.

\section{KESIMPULAN DAN SARAN}

Kesimpulan

1. Hasil analisis regresi berganda menunjukan persamaan $Y=6,045+0,419 \times 1+0,458 \times 2$, arah regresi yang dihasilkan adalah positif sehingga mengandung arti bahwa semakin meningkat variabel kecerdasan emosional dan komitmen organisasi maka kinerja pegawai juga akan meningkat

2. Kecerdasan emosional memiliki pengaruh yang signfiikan terhadap kinerja pegawai pada Dinas Ketenagakerjaan dan Transmigrasi Kabupaten Seluma. Hal ini dibuktikan dengan hasil pengujian hipotesis secara parsial (uji t) bahwa nilai signifkan sebesar 0,000 kecil dari 0,05. Artinya apabila kecerdasan emosional meningkat maka kinerja pegawai juga akan meningkat.

3. Komitmen organisasi memiliki pengaruh yang signfiikan terhadap kinerja pegawai pada Dinas Ketenagakerjaan dan Transmigrasi Kabupaten Seluma. Hal ini dibuktikan dengan hasil pengujian hipotesis secara parsial (uji t) bahwa nilai signifkan sebesar 0,000 kecil dari 0,05. Artinya apabila komitmen organsasi meningkat maka kinerja pegawai juga akan meningkat..

4. Kecerdasan emosional dan komitmen organisasi memiliki pengaruh yang signfiikan secara bersama-sama terhadap kinerja pegawai pada Dinas Ketenagakerjaan dan Transmigrasi Kabupaten Seluma. Hal ini dibuktikan dengan hasil pengujian hipotesis secara simultan (uji $\mathrm{f}$ ) bahwa nilai signifkan sebesar 0,000 kecil dari 0,05.

5. Nilai koefesien determinasi sebesar 0,595. Hal ini berarti bahwa X1 (kecerdasan emosional) dan X2 (komitmen organisasi) memiliki kontribusi terhadap kinerja ( $Y$ ) sebesar 59,5\% sedangkan sisanya $40,5 \%$ dipengaruhi oleh variabel-variabel lainnya yang tidak diteliti dalam penelitian ini. 
Saran

1. Diharapkan kepada Pegawai Dinas Ketenagakerjaan dan Transmigrasi Kabupaten Seluma untuk meningkatkan kecerdasan emosional dalam bekerja.

2. Disarankan kepada Pegawai Dinas Ketenagakerjaan dan Transmigrasi Kabupaten Seluma untuk lebih meningkatkan kesadaran bahwa pentingnya komitmen organisasi yang akan meningkatkan kesetiaan Pegawai terhadap organisasi.

\section{DAFTAR PUSTAKA}

Ambar, Teguh Sulistiyani dan Rosidah. 2016. Manajemen Sumber Daya Manusia. Yogyakarta : Graha Ilmu.

Ariesta. 2016. Pengaruh Kecerdasan Emosional Dan Organizational Citizenship Behavior (OCB) Terhadap Kinerja Peternak Ayam Ras Pedaging. Skripsi. Universitas Airlangga

Danim, Sudarwan. 2016. Kinerja Staf dan Organisasi. Bandung : Pustaka Setia

Ghozali, Imam. 2015. Aplikasi Analisis Multivariate Dengan Program SPSS. Semarang: Badan Penerbit Universitas Diponegoro

Goleman Daniel. 2015. Emotional Intelligence. Jakarta : Gramedia Utama

Luthans, Fred. 2014. Perilaku Organisasi. Edisi Sepuluh. Diterjemahkan oleh : Vivin Andhika Yuwono; Shekar Purwanti; Th.Arie Prabawati; dan Winong Rosari. Yogyakarta : Andi

Mahyudin Fajri. 2017. Hubungan Budaya Organisasi dan Komitmen Organisasi dengan Kinerja Pegawai Pada Bagian Administrasi Keuangan Sekretariat Daerah Provinsi Bengkulu. Skripsi. Universitas Dehasen

Mangkunegara. Anwar Prabu, 2015. Manajemen Sumber Daya Manusia Perusahaan. Bandung: PT. Remaja Rosdakarya

Muchlas Samanii, 2014. Konsep dan Model Pendidikan Karakter. Bandung Remaja Rosdakarya

Narimawati, Umi. 2014. Riset Manajemen Sumber Daya Manusia. Jakarta : Agung Media

Prawirosentono, Suryadi. 2016. Kebijakan Kinerja Karyawan. Yogyakarta:BPFE.

Shapiro Lawrence, E. 2016. Mengajarkan Kecerdasan Emosional Pada Anak. Jakarta : Gramedia Utama

Siagian, Sondang P, 2015, Manajemen Sumber Daya Manusia, Bumi Aksara, Jakarta

Soekidjan, 2016. Manjaemen Sumber Daya Manusia . Jakarta : Bumi Aksara

Sopiah. 2015. Perilaku Organisasi, Yogyakarta: Andi Offset.

Sugiyono, 2015. Statistika Untuk Penelitian. Cetakan keenam, Penerbit Alfabeta, Bandung.

Sutrisno, Edy. 2014. Manajemen Sumber Daya Manusia. Jakarta: Prenada Media Group

Thavaraj, S., Ramesh, 2016. Impact of emotional intelligence on academic achievement of college students -. International Journal of Business Management \& Research (IJBMR), 6(2), 25-30

Zainuddin. 2015. The Journalist. Jakarta : Prestasi Pustaka Publisher 